\title{
Measurements of Slope Distances and Zenith Angles At Augustine Volcano, Alaska 1986, 1988, and 1989
}

\author{
by \\ John A. Power and Eugene Y. Iwatsubo
}

Open-File Report 98-145

This report is preliminary.

Any use of trade, product or firm names is for descriptive purposes only and does not imply endorsement by the U.S. Geological Survey.

\author{
Alaska Volcano Observatory \\ Anchorage, Alaska \\ 1998
}




\section{U.S. DEPARTMENT OF THE INTERIOR \\ BRUCE BABBITT, Secretary}

U.S. GEOLOGICAL SURVEY

Thomas J. Casadevall, Acting Director

For additional information:

U.S. Geological Survey Alaska Volcano Observatory 4200 University Drive Anchorage, AK 99508

www.avo.alaska.edu
Copies of this report may be purchased from:

U.S. Geological Survey Branch of Information Services Box 25286

Denver, CO 80225-0286 


\section{CONTENTS}

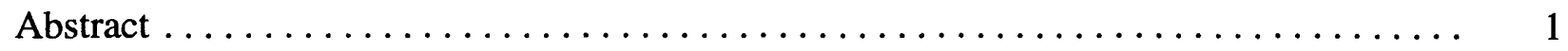

Introduction $\ldots \ldots \ldots \ldots \ldots \ldots \ldots \ldots \ldots \ldots \ldots \ldots \ldots \ldots \ldots \ldots \ldots \ldots \ldots, 1$

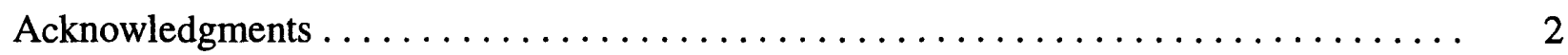

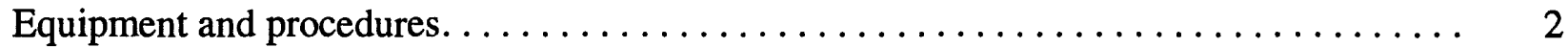

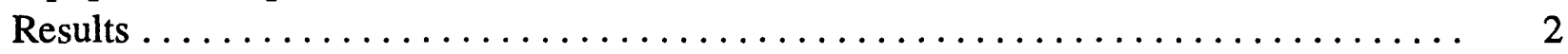

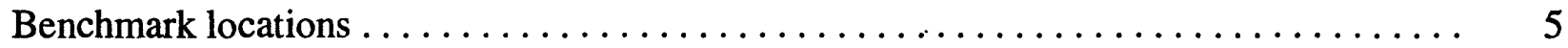

References cited........................................ 8

FIGURES

1. Map showing location of Augustine Volcano and communities surrounding

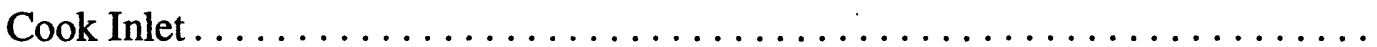

2. Map showing locations of benchmarks and slope distances measured at Augustine Volcano during 1986, 1988, and 1989

3-9. Photographs showing:

3. Augustine Volcano, summer 1988 , showing locations of benchmarks

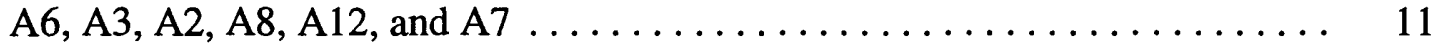

4. Augustine Volcano from the northeast, July $29,1994 \ldots \ldots \ldots \ldots \ldots \ldots . \quad 12$

5. Augustine Volcano as seen from benchmark Mound on July 13, 1995 . . . . . 13

6. Locations of benchmarks A1, A3, A5, West Augustine, and A6 . . . . . . . 14

7. Locations of benchmarks $A 4, A 8$, and A14, on July $27,1994 \ldots \ldots \ldots \ldots$.

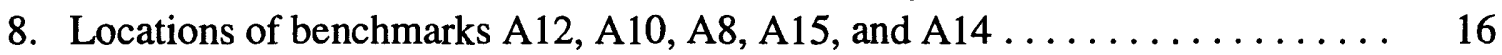

9. Augustine Volcano from benchmark A9, on July $29,1994 \ldots \ldots \ldots \ldots \ldots .17$

\section{TABLES}

1. Mark-to-mark slope distances and zenith angles measured in $1986 \ldots \ldots \ldots \ldots 2$

2. Mark-to-mark slope distances and observed differences at Augustine Volcano

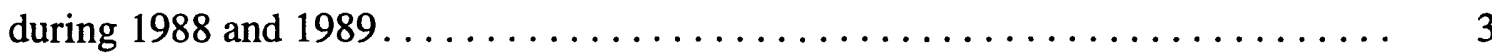

3. Mark-to-mark zenith angles measured at Augustine Volcano in 1988 and $1989 \ldots 4$ 


\title{
Measurements of Slope Distances and Zenith Angles At Augustine Volcano, Alaska, 1986, 1988, and 1989
}

\author{
by John A. Power ${ }^{1}$ and Eugene Y. Iwatsubo ${ }^{2}$
}

\section{ABSTRACT}

Between 1986 and 1989, a geodetic network was established on Augustine Volcano in south-central Alaska. Establishment of this network involved the installation of 14 new benchmarks and reoccupation of five existing marks on Augustine Island. In 1986, five lines were established. In 1988, 22 lines were added to the network. In 1989, many of the lines were remeasured, and three additional lines were added. The total network consists of 30 slope distances and zenith angles measured between 19 benchmarks. Slope distances were measured using an electronic distance measuring (EDM) system. Associated zenith angles were measured using a Wild T2 theodolite. This report contains mark-to-mark slope distances and zenith angles measured during 1986, 1988, and 1989, as well as descriptions and photographs of the benchmarks. Even though five of the lines were established prior to the end of the 1986 eruption, no displacements above expected measurement errors were detected.

\section{INTRODUCTION}

Between 1986 and 1989 the Alaska Volcano Observatory (AVO) established a trilateration network on Augustine Volcano. Augustine Volcano is located on a small island in the southwest portion of Cook Inlet, about $100 \mathrm{~km}$ southwest of Homer, Alaska (fig. 1). Augustine is an active volcano having six major eruptions recorded in historic time. These eruptions occurred in 1812, 1883, 1935, 1963-64, 1976, and 1986. Recent eruptions of

\footnotetext{
${ }^{1}$ Alaska Volcano Observatory, Anchorage, Alaska

${ }^{2}$ Cascades Volcano Observatory, Vancouver, Washington
}

Augustine have typically begun with an explosive onset followed by lava extrusions lasting over a period of several months (Swanson and Kienle, 1988; Power, 1988).

The trilateration network at Augustine consists of $30 \mathrm{EDM}$ lines and zenith angles shot from six instrument stations (fig. 2). The first five lines were measured on June 7, 1986. In July 1988, an additional 22 lines were established. The network was reoccupied and three additional lines were added in June 1989.

Geodetic monitoring of volcanoes has proven to be a useful predictive tool for forecasting volcanic eruptions. Geodetic information has also been used to model the depth and size of subsurface magma accumulations (Kinoshita and others, 1974; Lipman and others, 1981; Chadwick and others, 1988). Between 1980 and 1988, the U.S. Geological Survey's David A. Johnston Cascades Volcano Observatory (CVO) established baseline geodetic networks at a number of potentially active volcanoes in the Cascades (Iwatsubo and Swanson, 1992). Augustine Volcano's frequent eruptions may offer a special opportunity to study deformation associated with andesitic to dacitic volcanism. Reoccupation of the Augustine geodetic network following the next eruption may provide some constraints on the location and size of subsurface magma accumulations, as well as the overall stability of the Augustine cone. By analogy, measurements at Augustine may provide some insight into the extent and style of deformation might be expected at similar volcanoes and the type of measurements required to monitor these changes. 


\section{ACKNOWLEDGEMENTS}

Dan Dzurisin, Jurgen Kienle, John Paskievitch, Chris Nye, Larry Kodosky, and Betsy Yount assisted with installation and occupation of the network. Logistical assistance provided by Kachemak Air Service and Maritime Helicopters is gratefully acknowledged. John Paskievitch and Jeff Freymueller reviewed the text and figures.

\section{EQUIPMENT AND PROCEDURES}

By design, the trilateration network at Augustine closely resembles those at many of the Cascade volcanoes (Chadwick and others, 1985; Iwatsubo and others, 1988; Iwatsubo and Swanson, 1992). The benchmark installations, survey equipment, and procedures followed are as those described for the Cascades (Iwatsubo and others, 1988). Benchmarks normally used were standard 3.5-inch brass caps cemented to rock outcrops. It is hoped that many of these benchmarks will survive the next eruption of Augustine.
The distances at Augustine were measured with a Hewlett-Packard 3808 EDM in 1986 and 1988. A Geodimeter 114 was used to measure distances in 1989. Zenith angles were measured with a Wild T-2 theodolite. In 1986, endpoint temperatures were measured using standard hand-held thermometers. During the 1988 and 1989 surveys, endpoint temperatures were measured $6 \mathrm{~m}$ above the ground surface following the technique described by Iwatsubo and others (1988). Elevations and locations are calculated with respect to NAD27 and NVGD29.

\section{RESULTS}

Mark-to-mark slope distances and zenith angles for the five lines measured in 1986 are listed in table 1 . Table 2 lists the mark-to-mark slope distances and the calculated change based on endpoint temperatures and pressures between 1988 and 1989. Table 3 lists the zenith angles measured in 1988 and 1989. Coordinates calculated for each benchmark are listed with the descriptions in the "Benchmark Locations" section. Coordinates were calculated using the method described by Iwatsubo and Swanson (1992).

Table 1. Mark-to-mark slope distances and zenith angles measured in 1986

\begin{tabular}{lcc}
\hline \multicolumn{1}{c}{ Instrument reflector } & Distance (meters) & Zenith angle \\
\hline West Augustine - South Augustine & 6913.0206 & $90^{\circ} 07^{\prime} 47^{\prime \prime}$ \\
South Augustine - Kamishak & 5564.5858 & $84^{\circ} 49^{\prime} 07^{\prime \prime}$ \\
Mound - A2 & 4047.1496 & $79^{\circ} 09^{\prime} 33^{\prime \prime}$ \\
Mound - A4 & 4107.5430 & $76^{\circ} 48^{\prime} 22^{\prime \prime}$ \\
Burr Auxiliary - Mound & 5763.7005 & $89^{\circ} 05^{\prime} 46^{\prime \prime}$ \\
\hline
\end{tabular}


Table 2. Mark-to-mark slope distances and observed differences at Augustine Volcano during 1988 and 1989

\begin{tabular}{|c|c|c|c|}
\hline \multirow{2}{*}{ Instrument reflector } & \multicolumn{2}{|c|}{ Distance (meters) } & \multirow{2}{*}{ Difference } \\
\hline & 1988 & 1989 & \\
\hline West Augustine - A1 & 6014.5365 & 6014.5320 & -0.0045 \\
\hline West Augustine - A3 & 7067.1485 & -- & -- \\
\hline West Augustine - A5 & 1540.1411 & 1540.1389 & -0.0022 \\
\hline West Augustine - A6 & 6237.0521 & 6237.0548 & +0.0027 \\
\hline West Augustine - A7 & 6102.3246 & 6102.3324 & +0.0078 \\
\hline West Augustine - A8 & 6831.2637 & 6831.2637 & +0.0000 \\
\hline West Augustine - A10 & 6987.7236 & 6987.7138 & -0.0098 \\
\hline West Augustine - South Augustine & 6913.0226 & 6913.0164 & -0.0062 \\
\hline South Augustine - A7 & 6330.3207 & -- & -- \\
\hline South Augustine - A10 & 6658.2012 & -- & -. \\
\hline South Augustine - A12 & 6368.3544 & 6368.3509 & -0.0035 \\
\hline South Augustine - Kamishak & 5564.5635 & 5564.5677 & +0.0042 \\
\hline A9 - Kamishak & 2874.3693 & 2874.3480 & -0.0213 \\
\hline A9 - A11 & 3254.8157 & 3254.8231 & +0.0074 \\
\hline A9 - A12 & 4332.0542 & 4332.0472 & -0.0070 \\
\hline A9 - A14 & 4265.6306 & 4265.6477 & 0.0171 \\
\hline Mound - A2 & 4047.1403 & 4047.1374 & -0.0029 \\
\hline Mound - A3 & -- & 4024.5919 & -- \\
\hline Mound - A4 & 4107.5395 & 4107.5629 & +0.0234 \\
\hline Mound - A11 & 3048.0769 & 3048.0759 & -0.0010 \\
\hline Mound - A14 & 4351.4988 & 4351.4969 & -0.0019 \\
\hline Mound - A15 & -- & 4423.3404 & -- \\
\hline Burr Auxiliary - Mound & 5763.6883 & 5763.6938 & +0.0055 \\
\hline Burr Auxiliary - A1 & 3605.0638 & 3605.0575 & -0.0063 \\
\hline Burr Auxiliary - A3 & 5021.2877 & 5021.2998 & +0.0121 \\
\hline Burr Auxiliary - A4 & 5625.1659 & 5625.2072 & +0.0413 \\
\hline Burr Auxiliary - A6 & 4732.0497 & 4732.0424 & -0.0073 \\
\hline Burr Auxiliary - A7 & 5752.7529 & 5752.7511 & -0.0018 \\
\hline Burr Auxiliary - A8 & 5713.6954 & 5713.7206 & +0.0252 \\
\hline Burr Auxiliary - A15 & -- & 5755.4581 & -- \\
\hline
\end{tabular}


Table 3. Mark-to-mark zenith angles measured at Augustine Volcano in 1988 and 1989

\begin{tabular}{|c|c|c|}
\hline \multirow{2}{*}{ Instrument reflector } & \multicolumn{2}{|c|}{ Zenith angle } \\
\hline & 1988 & 1989 \\
\hline West Augustine - A1 & $87^{\circ} 01^{\prime} 56^{\prime \prime}$ & $87^{\circ} 01^{\prime} 56^{\prime \prime}$ \\
\hline West Augustine - A3 & $83^{\circ} 19^{\prime} 34^{\prime \prime}$ & -- \\
\hline West Augustine - A5 & $90^{\circ} 33^{\prime} 44^{\prime \prime}$ & $90^{\circ} 33^{\prime} 39^{\prime \prime}$ \\
\hline West Augustine - A6 & $84^{\circ} 10^{\prime} 22^{\prime \prime}$ & -- \\
\hline West Augustine - A7 & $81^{\circ} 55^{\prime} 57^{\prime \prime}$ & $81^{\circ} 55^{\prime} 32^{\prime \prime}$ \\
\hline West Aug - A8 & $80^{\circ} 05^{\prime} 51^{\prime \prime}$ & $80^{\circ} 05^{\prime} 44^{\prime \prime}$ \\
\hline West Augustine - A10 & $80^{\circ} 06^{\prime} 51^{\prime \prime}$ & $80^{\circ} 06^{\prime} 42^{\prime \prime}$ \\
\hline West Augustine - South Augustine & $90^{\circ} 07^{\prime} 41^{\prime \prime}$ & $90^{\circ} 07^{\prime} 51^{\prime \prime}$ \\
\hline South Augustine - A7 & $82^{\circ} 04^{\prime} 52^{\prime \prime}$ & -- \\
\hline South Augustine - A10 & $79^{\circ} 29^{\prime} 09^{\prime \prime}$ & -- \\
\hline South Augustine - A12 & $80^{\circ} 18^{\prime} 34^{\prime \prime}$ & $80^{\circ} 18^{\prime} 23^{\prime \prime}$ \\
\hline South Augustine - Kamishak & $84^{\circ} 49^{\prime} 37^{\prime \prime}$ & $84^{\circ} 49^{\prime} 11^{\prime \prime}$ \\
\hline A9 - Kamishak & -- & $80^{\circ} 11^{\prime} 02^{\prime \prime}$ \\
\hline A9 - A11 & $86^{\circ} 54^{\prime} 02^{\prime \prime}$ & $86^{\circ} 54^{\prime} 00^{\prime \prime}$ \\
\hline A9 - A12 & $75^{\circ} 50^{\prime} 20^{\prime \prime}$ & $75^{\circ} 50^{\prime} 20^{\prime \prime}$ \\
\hline A9 - A14 & $74^{\circ} 30^{\prime} 37^{\prime \prime}$ & -- \\
\hline Mound - A11 & $88^{\circ} 08^{\prime} 55^{\prime \prime}$ & $88^{\circ} 08^{\prime} 56^{\prime \prime}$ \\
\hline Mound - A2 & $79^{\circ} 09^{\prime} 50^{\prime \prime}$ & $79^{\circ} 09^{\prime} 48^{\prime \prime}$ \\
\hline Mound - A3 & -- & $79^{\circ} 08^{\prime} 25^{\prime \prime}$ \\
\hline Mound - A4 & $76^{\circ} 48^{\prime} 23^{\prime \prime}$ & $76^{\circ} 48^{\prime} 26^{\prime \prime}$ \\
\hline Mound - A11 & $88^{\circ} 08^{\prime} 55^{\prime \prime}$ & $88^{\circ} 08^{\prime} 56^{\prime \prime}$ \\
\hline Mound - A14 & $75^{\circ} 52^{\prime} 51^{\prime \prime}$ & $75^{\circ} 52^{\prime} 44^{\prime \prime}$ \\
\hline Mound - A15 & -- & $75^{\circ} 30^{\prime} 31^{\prime \prime}$ \\
\hline Burr Auxiliary - Mound & $89^{\circ} 05^{\prime} 47^{\prime \prime}$ & - \\
\hline Burr Auxiliary - A1 & $84^{\circ} 47^{\prime} 02^{\prime \prime}$ & $84^{\circ} 46^{\prime} 59^{\prime \prime}$ \\
\hline Burr Auxiliary - A3 & $80^{\circ} 23^{\prime} 47^{\prime \prime}$ & $80^{\circ} 23^{\prime} 52^{\prime \prime}$ \\
\hline Burr Auxiliary - A4 & $79^{\circ} 28^{\prime} 04^{\prime \prime}$ & $79^{\circ} 28^{\prime} 05^{\prime \prime}$ \\
\hline Burr Auxiliary - A6 & $82^{\circ} 06^{\prime} 32^{\prime \prime}$ & $82^{\circ} 06^{\prime} 43^{\prime \prime}$ \\
\hline Burr Auxiliary - A7 & $81^{\circ} 16^{\prime} 13^{\prime \prime}$ & $81^{\circ} 1628^{\prime \prime}$ \\
\hline Burr Auxiliary- A8 & $77^{\circ} 57^{\prime} 54^{\prime \prime}$ & -- \\
\hline Burr Auxiliary - A15 & -- & $77^{\circ} 59^{\prime} 28^{\prime \prime}$ \\
\hline
\end{tabular}


Measurements between West Augustine and A3, South Augustine and A7, and South Augustine and A10 were not repeated in 1989 due to inclement weather and logistical constraints. Measurements between Mound and A3, Mound and A15, and Burr Auxiliary and A15 were not made until 1989. No significant changes were observed in slope distances or zenith angles between the surveys conducted in 1986, 1988, and 1989. The two largest changes occurred on the Mound to A4 and Burr to A4 lines, which suggests that A4 might be an unstable benchmark. All other measured changes are within expected error of $2 \mathrm{~cm} \pm$ $1.5 \mathrm{ppm}$ (Iwatsubo and others, 1988).

During September 1986, Augustine Volcano experienced a significant dome building eruption which marked the final phase of the 1986 eruptive activity. This eruptive phase was characterized by the addition of material to the summit dome, the establishment of a summit spine, and large pyroclastic flows that formed as a result of dome collapse (Swanson and Kienle, 1988; Power, 1988). The data from these surveys suggest that neither the $\mathrm{A} 2$ nor the A4 benchmarks experienced significant displacement as a result of this eruptive activity.

Many of the marks in the Augustine trilateration network were surveyed using GPS receivers during the summers of 1992, 1993, and 1995. Data from these surveys are archived at the Cascades Volcano Observatory in Vancouver, Washington.

\section{BENCHMARK LOCATIONS}

Benchmarks A1 through A15 (there is no A13) are 3.75-inch bronze caps that are engraved "US Department of Interior - Geological Survey, Cascades Volcano Observatory - Vancouver Washington." Measurements to each of these marks are made to a central point that is punched within a 0.25 -inch engraved square. The exception to this is mark A5, which is 2.5 -inch plain brass cap. These marks were installed using the technique described by Doukas and Ewert (1992). Benchmarks Kamishak, Mound, South Augustine, West Augustine, and Burr Auxiliary were established prior to this network and original descriptions can be obtained from the National Geodetic Survey. Many of these original benchmarks have subsidiary reference marks. Photographs showing locations of the benchmarks are shown in figures 3-9.

West Augustine - 103.2 feet elevation (59 23.1049' N, 153 ${ }^{\circ}$ 32.4712' W). The benchmark is located on the highest mound on the west island of Augustine. The top of the knoll is covered with rocks, boulders, and grass. The sides of the mound are covered by thick trees. A landing site exists in a meadow south of the benchmark at the base of the mound. From the landing site, go through trees and brush to the top of the mound. The benchmark is 5 feet south of the top of the mound in a rock outcrop. The benchmark is stamped "WEST AUGUSTINE," but it is very faint.

South Augustine - 52.72 feet elevation (59 ${ }^{\circ}$ 19.4319' $N 1^{\prime} 3^{\circ} 31.2773$ ' $W$ ). The benchmark is located on the southwest part of Augustine Island. The mark sits on a tall grass-covered sand dune that runs parallel to the shore, and is approximately 225 feet northwest and upslope from an old shack. To the north of the ridge are three large shallow pools. An old wooden platform is located 30 feet west of the mark. The benchmark is a disk on a 2-inch pipe that has been driven into the ground. The benchmark is stamped "S AUGUSTINE 2 1964." There are also two reference marks in 2-inch pipes that protrude about 18 inches above ground. These are stamped "S AUGUSTINE 2 NO 2 1964," and "S AUGUSTINE 2 NO 3 1964."

Kamishak - 1699.30 feet in elevation $\left(59^{\circ}\right.$ 20.7792' $N 1^{\prime} 153^{\circ} 26.0639^{\prime} W$ ). The benchmark is located on a prominent knoll along a southtrending ridge on the upper south slope of 
Augustine Island. The landing area is located north (300 feet) of the mark in a saddle between the base of the knoll and the beginning of the steep slope towards the top of the volcano. The benchmark is in a boulder on top of the knoll that is flush with the ground. It is stamped "KAMISHAK 1946." A second mark is cemented to a boulder about 12 feet to the south.

Mound - 346.90 feet in elevation $\left(59^{\circ}\right.$ 22.2808' $N 1^{\circ}{ }^{\circ} 21.1742 '$ 'W). The benchmark is located on the largest prominent hill on the east side of Augustine Island. The landing area is located is to the west and downslope at the base of the hill in a flat area. The benchmark is stamped "AUGUSTINE 1908 46."

Burr Auxiliary - 48.99 feet elevation $\left(59^{\circ}\right.$ 24.7524' $N 1^{\circ}{ }^{\circ} 24.8575$ ' W). The benchmark is located on a low arcuate ridge on the northern shore of Augustine Island. It is in a lowlying outcrop just west of the existing Burr Point Hut. The benchmark is on the lip of the hill just southwest of the entrance of the hut. The mark is a plain brass cap with no markings.

A1 - 1124.52 feet elevation $\left(59^{\circ} 22.9328^{\prime} \mathrm{N}\right.$, $153^{\circ} 26.1402^{\prime}$ ). The benchmark is located on a prominent lava flow on the northwest side of Augustine Island. Benchmark can be found just downslope from the AUL seismic station antenna and almost directly on top of the AUL seismometer. Helicopter landing is upslope from the seismic site. Benchmark is stamped "A1 1988."

A2 - 2843.17 feet elevation (59 $22.0365^{\prime} \mathrm{N}$, $153^{\circ} 25.3409^{\prime}$ W). The benchmark is located about 150 feet along ridge connecting prominent knob on northeast flank to the volcano. Helicopter landing is on top of prominent round knob. Benchmark is stamped "A2."

A3 - 2797.58 feet elevation $\left(59^{\circ} 22.0969^{\prime} \mathrm{N}\right.$, $153^{\circ} 25.3318$ ' W). The mark is located on prominent round knob on northeast side of volcano. Helicopter landing site is on top of knob, the same location as for benchmark A2. A3 is located approximately 150 feet NNW and 30 feet lower than landing site. Mark is on rock outcrop that stands up about 2.5 feet. A rock cairn was built nearby and painted orange when benchmark was installed. Benchmark is stamped "A3 1988."

A4 - 3422.64 feet elevation $\left(59^{\circ} 21.7816^{\prime} \mathrm{N}\right.$, $153^{\circ} 25.2792^{\prime}$ ). Benchmark is located about 100 feet above seismic station AUP, on a small outcrop of rock just above flat bench. Helicopter landing is on flat bench. Benchmark is stamped "A4."

A5 - 53.44 feet elevation $\left(59^{\circ} 22.7269^{\prime} \mathrm{N}\right.$, $153^{\circ} 31.0241 '$ ' $)$. The benchmark is located north of the Augustine Hut, about threefourths of the way from the hut to the break in slope above the lagoon. It is on a large flat rock located northeast of the trail leading from the hut to the lagoon. It is on top of the bluff overlooking the northeast part of the lagoon. The mark is a plain brass cap stamped "A5 1988."

A6 - 2180.56 feet elevation $\left(59^{\circ} 22.3103\right.$ ' $\mathrm{N}$, $153^{\circ} 26.1107, W$ ). The benchmark is located on the upper slope of the prominent ridge on the northeast side of Augustine Island. The mark is located on a low red/yellow outcrop flush with the ground 175 feet N10E of the telemetered GPS station called "Windy." Helicopter landing is easy in small saddle between main volcano and lava flow just to the south of telemetered GPS site. Benchmark is stamped "A6 1988."

A7 - 2913.50 feet elevation $\left(59^{\circ} 21.8236^{\prime} \mathrm{N}\right.$, $153^{\circ} 26.6106^{\prime} \mathrm{W}$ ). The benchmark is located in an outcrop on the western edge of a prominent lava dome (Dome $\mathrm{H}$ ) on the west side of the volcano. Seismic station AUH is approximately 75 feet northwest of the mark. From the mark, West Augustine, South Augustine, and Burr Auxiliary benchmarks can all be seen. Helicopter landing is easy on many flat spots above the mark. Benchmark is stamped "A7 1988." 
A8 - 3957.52 feet elevation $\left(59^{\circ} 21.7864^{\prime} \mathrm{N}\right.$, $\left.153^{\circ} 25.8567, \mathrm{~W}\right)$. Benchmark is on top of 1935 dome remnant on NW side of summit dome complex. Best helicopter landing site is on prominent flat on west side of volcano several hundred feet below summit. To ascend to the mark, climb up the steep south face of the 1935 dome remnant. This climb is very steep (a class 5 rock climb) and requires the use of both hands and feet. Benchmark is stamped "A8 1988."

A9 - 92.31 feet elevation $\left(59^{\circ} 19.4198^{\prime} \mathrm{N}\right.$, $153^{\circ} 24.7097^{\prime}$ W). Benchmark is located on the southwest portion of a point of land extending from the southern shore of Augustine Island. Landing is in a broad flat grassy area just north (30 to 40 feet) of the prominent outcrop containing the mark. The benchmark is located on the upper north side of the largest outcrop in the area. An old benchmark "GRUB" is located about 300 feet west of A9 on a smaller outcrop. Benchmark is stamped "A9 1988."

A10 - 4038.94 feet elevation $\left(59^{\circ} 21.5991\right.$ ' $\mathrm{N}$, $\mathbf{1 5 3}^{\circ} 25.8337$ ' W). Benchmark is high on south rim of 1964 dome remnant. Mark is about 90 feet east of prominent notch in south rim, where AUS seismic station is located. Traveling east to west, this is the first notch that can be easily climbed onto the south face of the volcano. Climb up the outside of the 1964 rim from the notch to reach the benchmark. Landing site is in the broad flat area within the $1964 \mathrm{rim}$. The benchmark is in a rock outcrop back 5 to 10 feet from the edge of the rim. Benchmark is stamped "A10 1988."

A11 - 669.86 feet elevation $\left(59^{\circ} 20.9584^{\prime} \mathrm{N}\right.$, $153^{\circ} 23.0766^{\prime} \mathrm{W}$ ). Benchmark is located on a low ridge of large boulders on the southeast side of Augustine Island. The benchmark is in a flat-topped boulder projecting up 3 to 5 feet that forms a flat ledge. The benchmark is approximately 30 feet upslope from the largest boulder on the ridge. In 1988, several red buoys were moved from the beach and tied to boulders near the mark. Benchmark is stamped "A11 1988."

A12 - 3569.56 feet elevation $\left(59^{\circ} 21.5612\right.$ ' $N$, $153^{\circ} 26.1365^{\prime}$ W). This benchmark is on a prominent rock knob on the southwestern shoulder of Augustine Volcano. The mark is on the southern-most remnant of the 1935 dome. Helicopter landing is well above the benchmark in the flat between the 1964, 1986, and 1935 domes (same landing site as used for A8). From the landing site, descend several hundred feet to the south to reach the mark. Benchmark is stamped "A12 1988."

A14 - 3829.75 feet elevation $\left(59^{\circ} 21.6033^{\prime} \mathrm{N}\right.$, $153^{\circ} 25.4237^{\prime}(W)$. The benchmark is high on the east end of the 1964 dome remnant, which forms the present crater rim and summit. To reach the mark, traverse around the northeast end of this rim on the tephra ramp. Climb up talus onto the east face of the volcano (outside of 1964 dome) and ascend approximately 300 feet to northeast end of crater rim. Benchmark is on a rock outcrop projecting approximately 6 feet up, which is set back roughly 10 feet from the crater edge. A small rock cairn marks the benchmark. The climb is fairly exposed. Bearings from the mark to several points are N33E to highest pinnacle, N75E to BM Mound, and S7E to BM A9. Benchmark is stamped "A14 1988."

A15 - 3977.43 feet elevation $\left(59^{\circ} 21.7422^{\prime} \mathrm{N}\right.$, $153^{\circ} 25.5702$ ' W). Benchmark is on a nondescript boulder about 150 feet east of the Domo tiltmeter site and dome helicopter landing area. A small rock cairn is constructed near the mark. Benchmark is stamped "A15 1988." 


\section{REFERENCES CITED}

Chadwick, W.W., Iwatsubo, E.Y., Swanson, D.A., and Ewert, J.W., 1985, Measurements of slope distances and vertical angles at Mount Baker and Mount Rainier, Washington, Mount Hood and Crater Lake, Oregon, and Mount Shasta and Mount Lassen, California, 1980-1984: U.S. Geological Survey Open File Report 85-205, 96 p.

Chadwick, W.W., Jr., Archuleta, R.J., and Swanson, D.A., 1988, The mechanics of ground deformation precursory to dome building extrusions at Mount St. Helens, 1981-1982: Journal of Geophysical Research, v. 93, p. 4351 - 4366.

Doukas, M.P., and Ewert, J.E., 1992, Installation of benchmarks and permanent reflectors for geodetic deformation networks, in Ewert J.E. and Swanson D.A., (eds.), Monitoring volcanoesTechniques and strategies used by the staff of the Cascades Volcano Observatory, 1980-1990: U.S. Geological Survey Bulletin 1966, p. 115 124.

Iwatsubo, E.Y., Topinka, L., and Swanson, D.A., 1988, Measurements of slope distances and zenith angles at Newberry and South Sister Volcanoes, Oregon, 1985-1986: U.S. Geological Survey Open File Report 88-377, 51 p.
Iwatsubo E.Y., and Swanson, D.A., 1992, Trilateration and other distance measuring techniques used at Cascade and other volcanoes, in Ewert J.E. and Swanson D.A., (eds.), Monitoring volcanoes-Techniques and strategies used by the staff of the Cascades Volcano Observatory, 19801990: U.S. Geological Survey Bulletin 1966, p. 53-68.

Kinoshita, W.T., Swanson, D.A., and Jackson, D.B., 1974, The measurement of crustal deformation related to volcanic activity at Kilauea Volcano, Hawaii, in Civetta, L., Gasparini, P., Luongo, G., and Rapolla, A., eds., Physical volcanology: Amsterdam, Elsevier, p. 87-115.

Lipman, P.W., Moore, J.G., and Swanson, D.A. 1981, Bulging of the north flank before the May 18 eruption-Geodetic data, in Lipman, P.W. and Mullineaux, D.R., eds., The 1980 eruptions of Mount St. Helens, Washington: U.S. Geological Survey Professional Paper 1250, p. 143-155.

Power, J.A., 1988, Seismicity associated with the 1986 eruption of Augustine Volcano, Alaska: M.S. thesis, University of Alaska, Fairbanks, 142 p.

Swanson, S. E., and Kienle, J., 1988, The 1986 eruption of Mount St. Augustine-Field test of a hazard evaluation: Journal of Geophysical Research v. 93, p. $4500-4520$. 


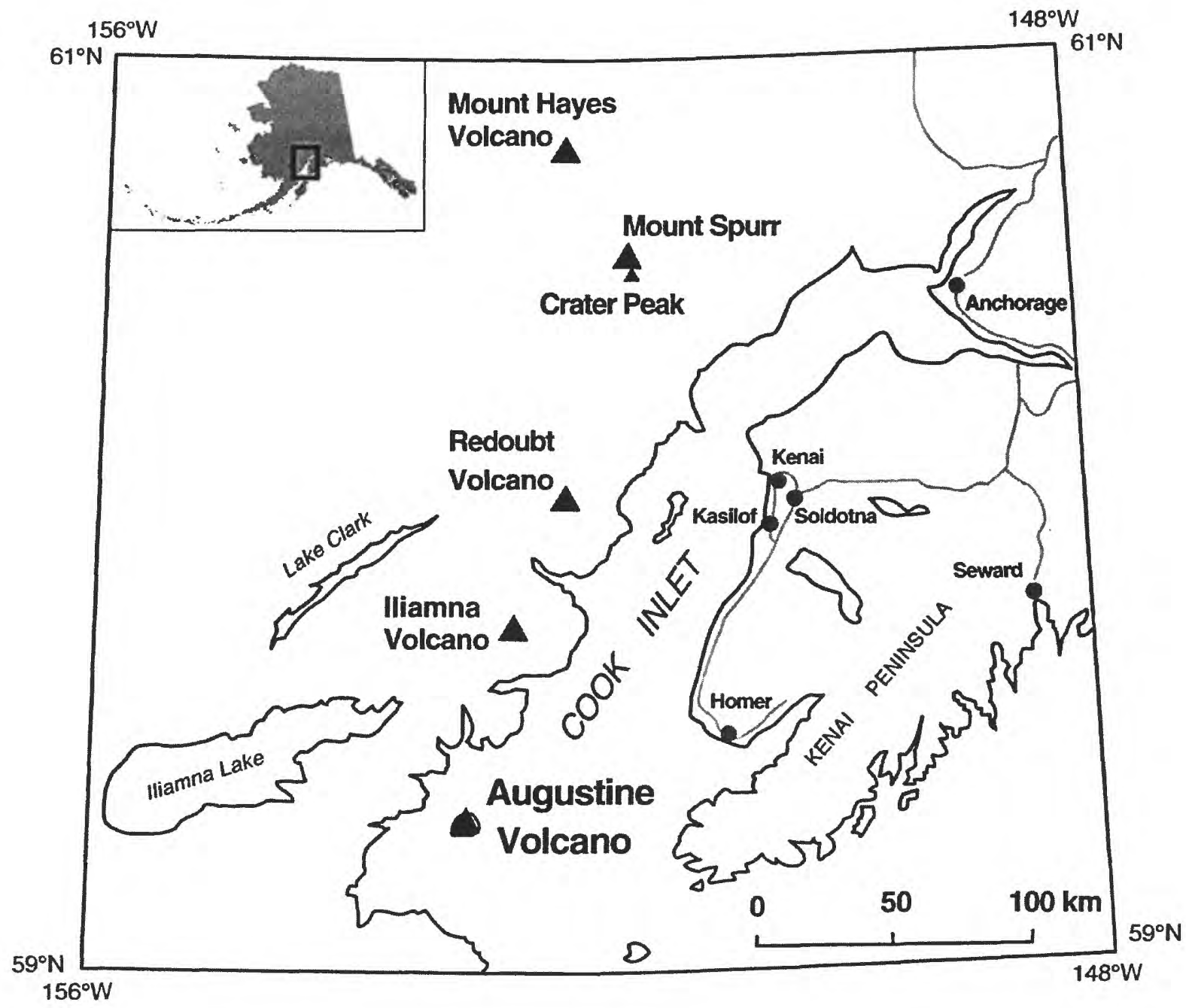

Figure 1. Location of Augustine Volcano and communities surrounding Cook Inlet. 


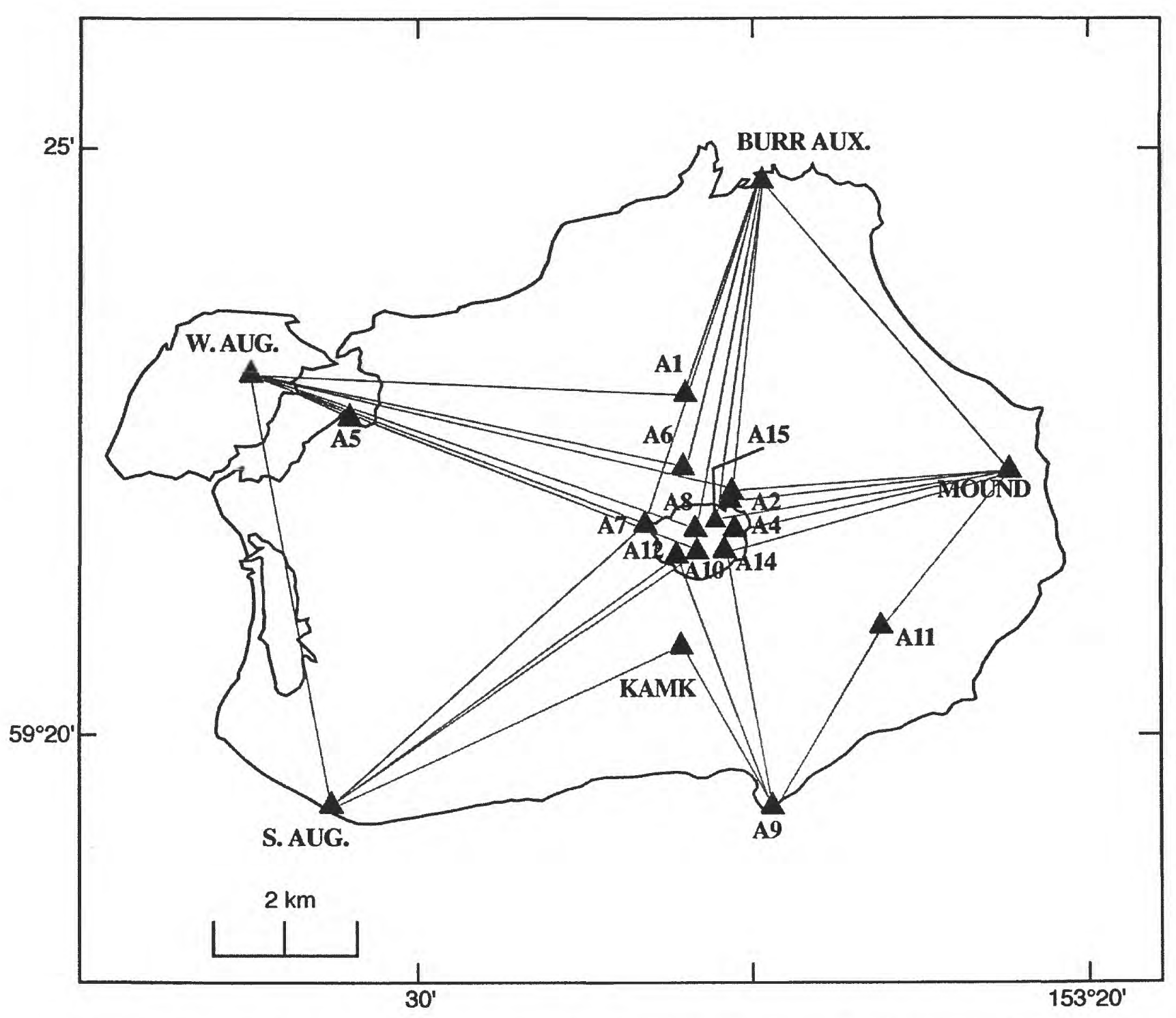

Figure 2. Locations of benchmarks and slope distances measured at Augustine Volcano during 1986, 1988, and 1989. 

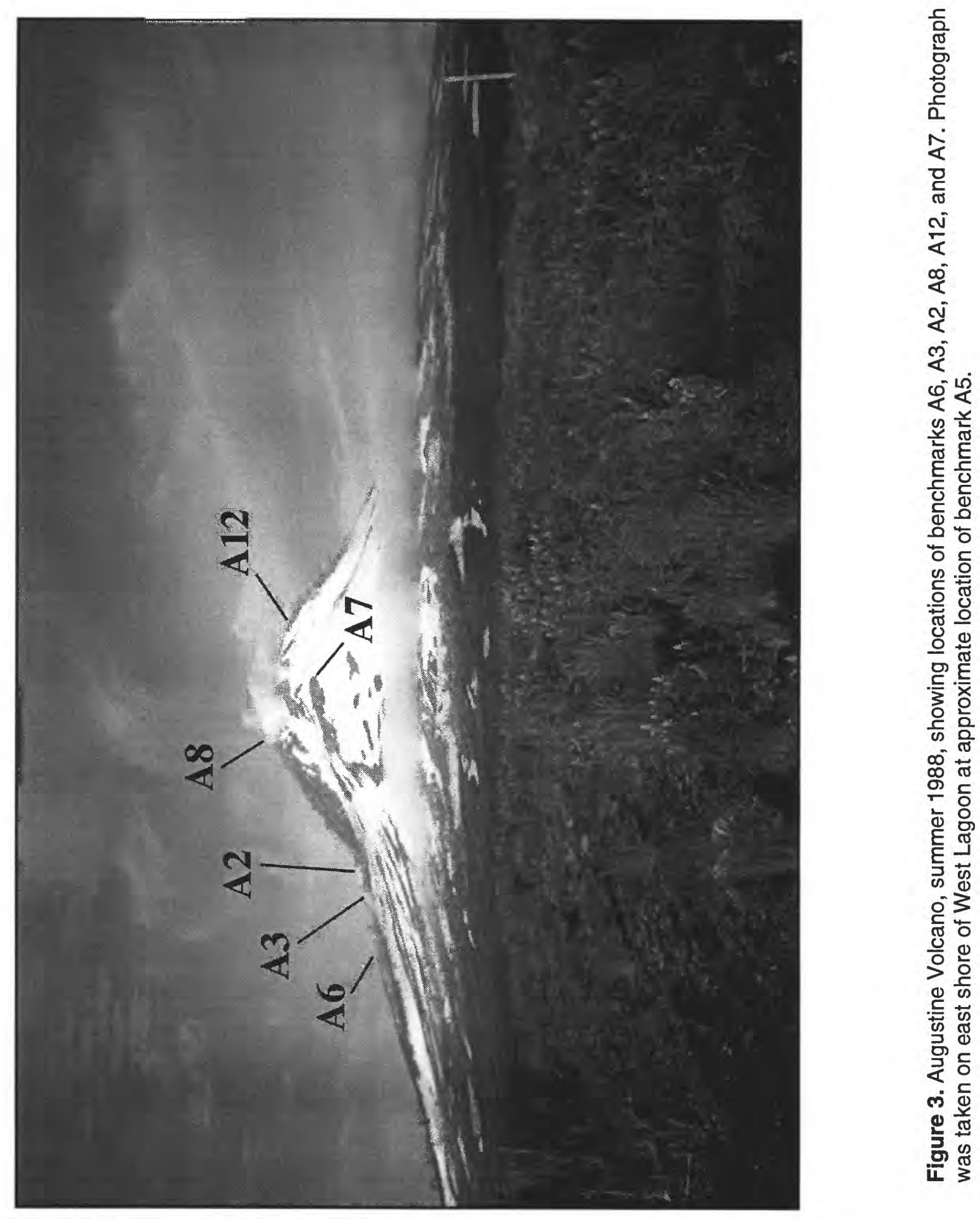


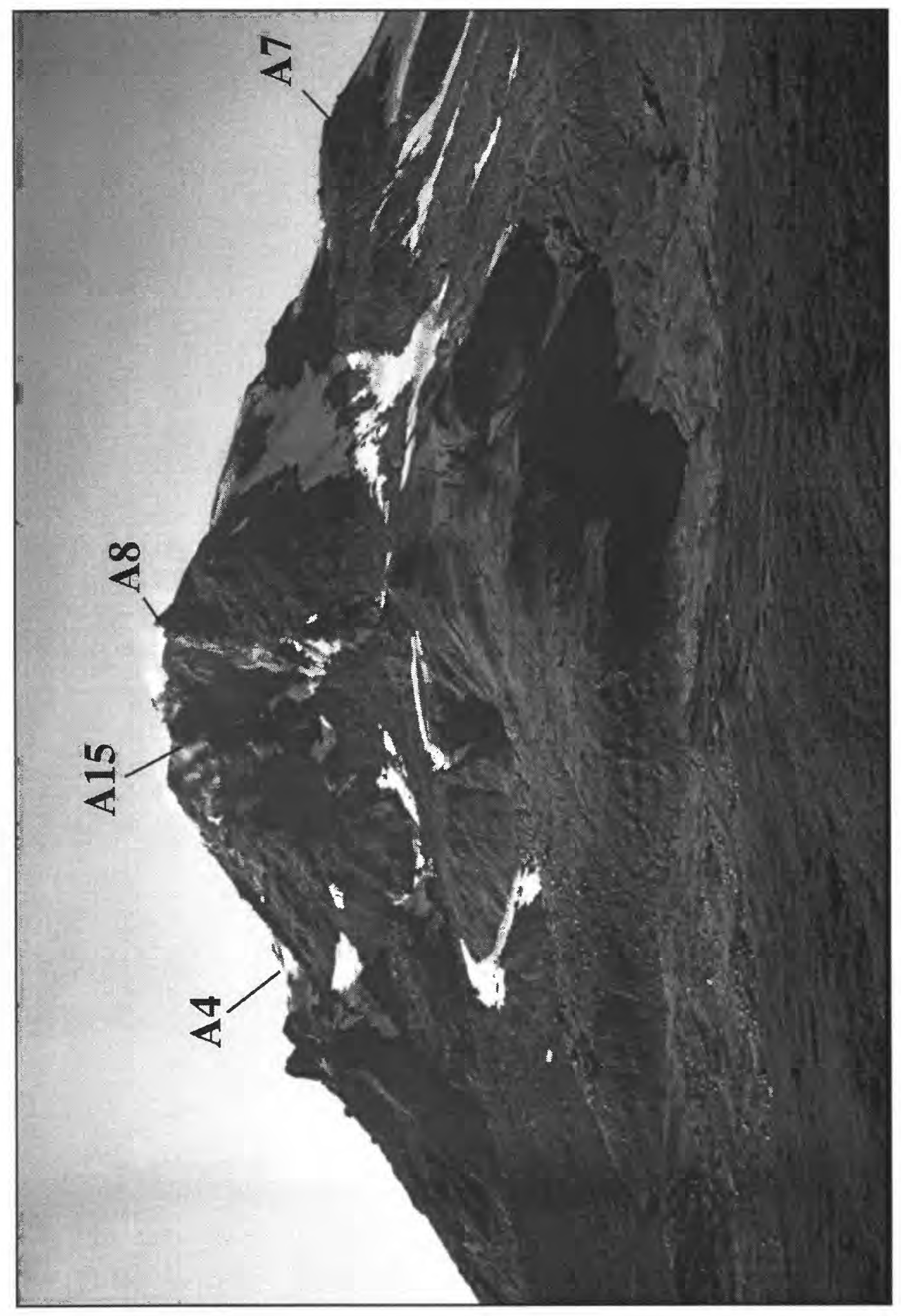

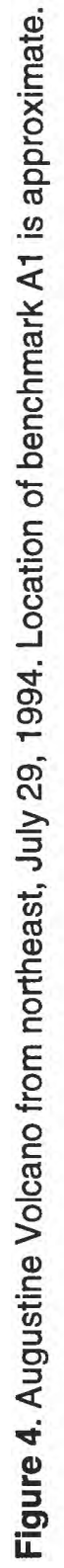




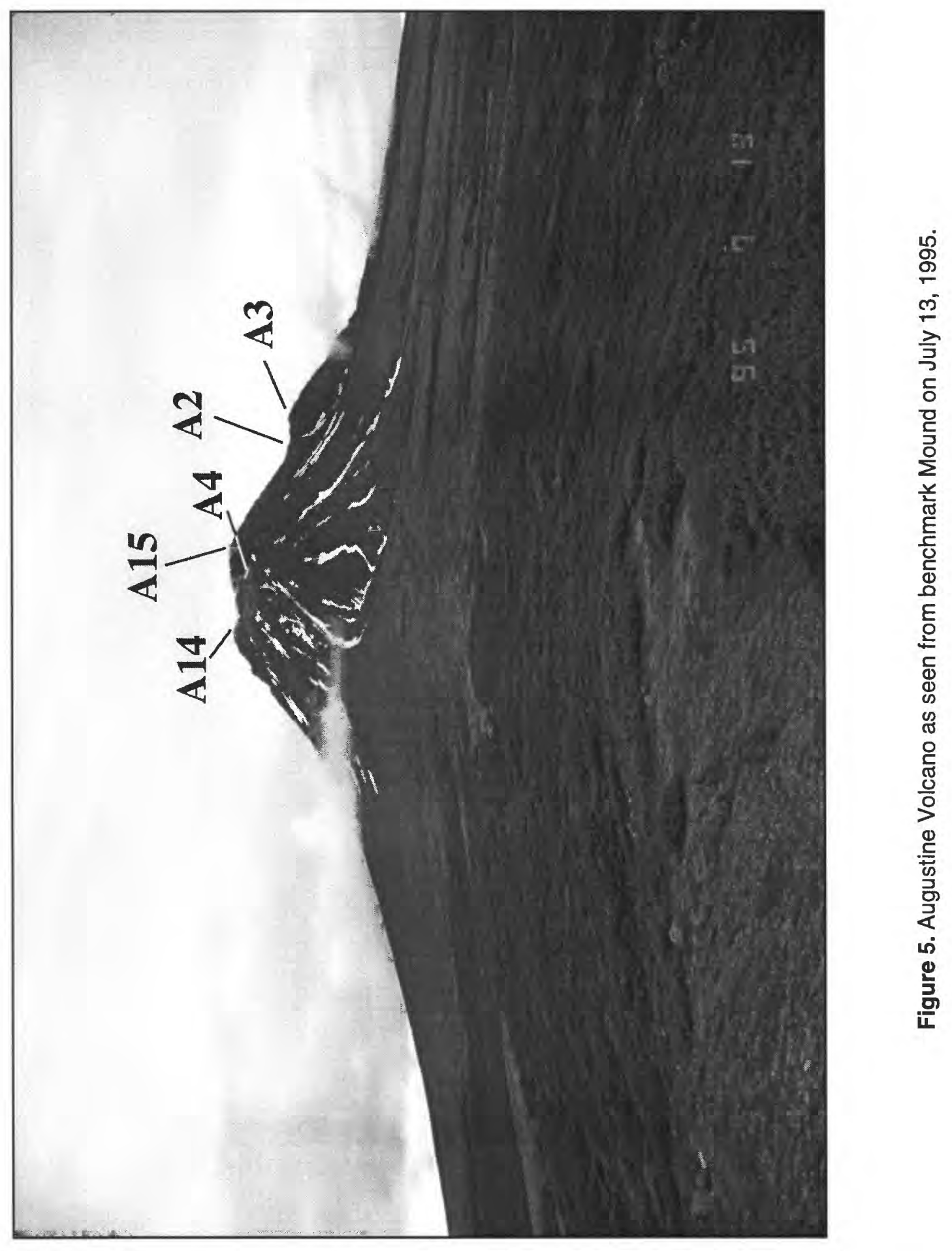



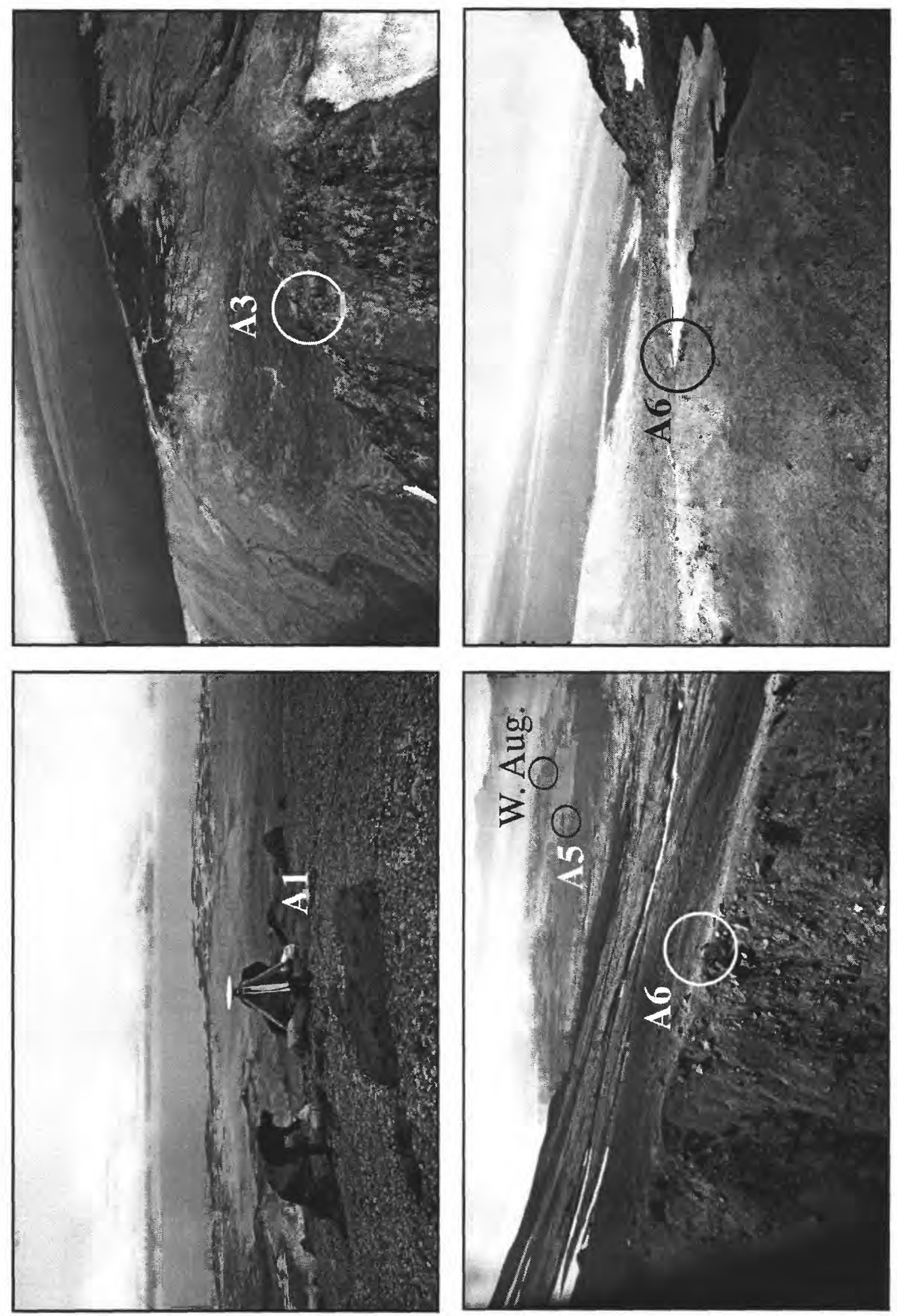

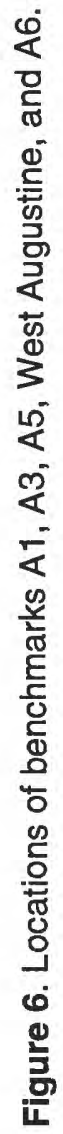



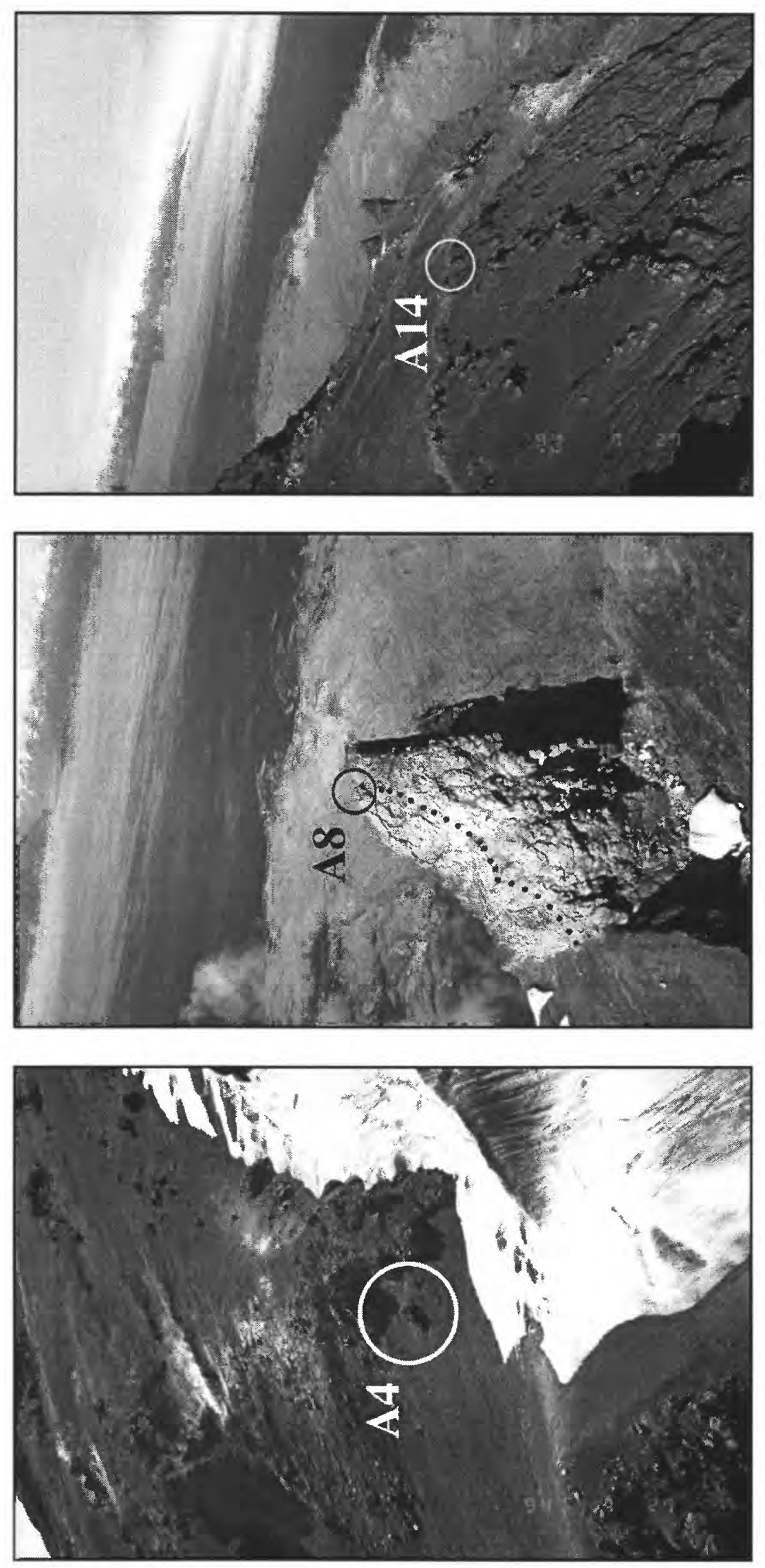

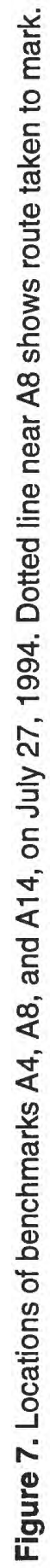



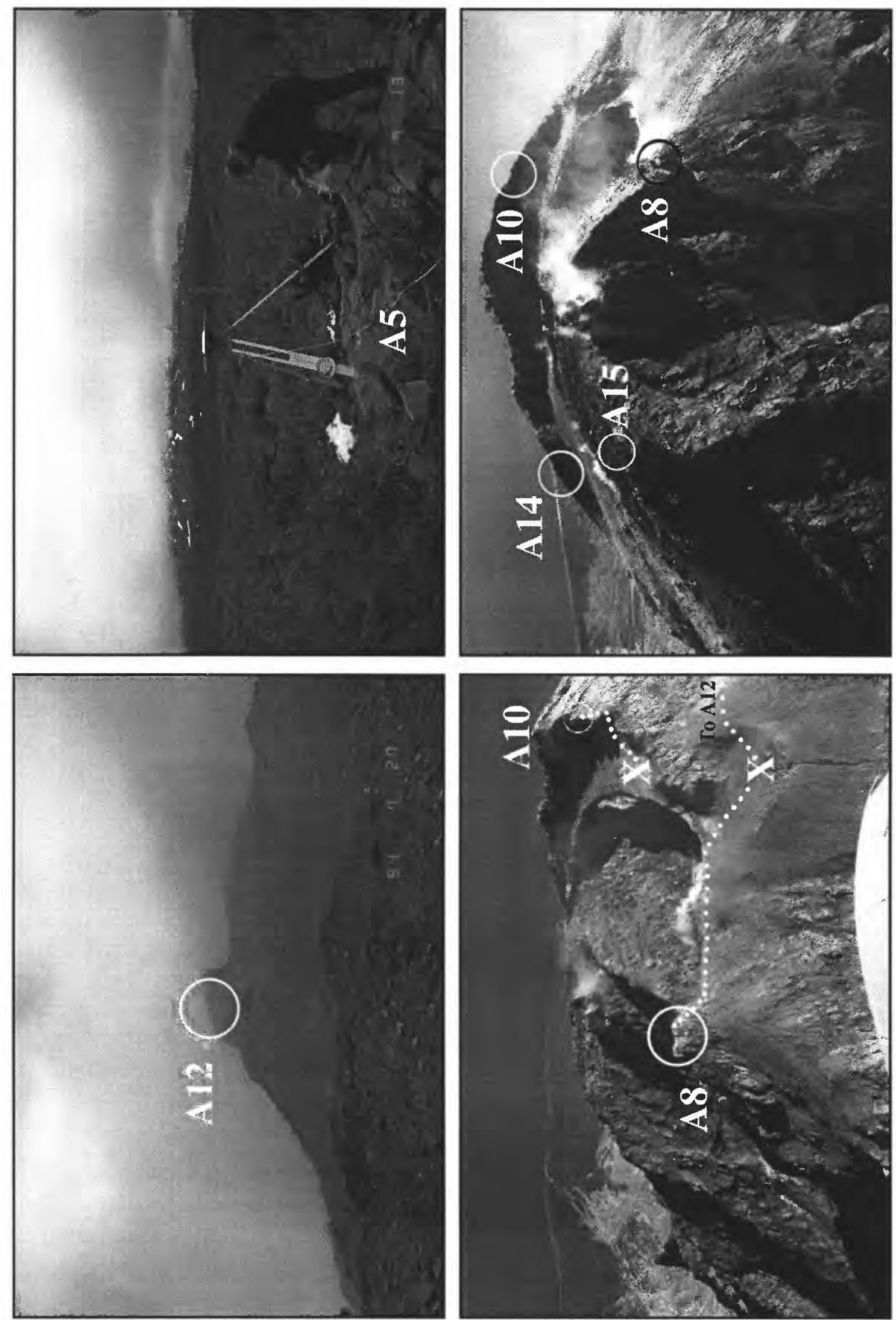

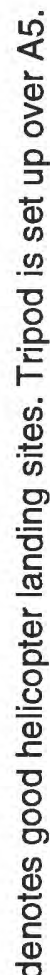

$\times$

$\frac{ \pm}{\pi}$

음

15

这

$\infty \frac{1}{4}$

응

으 흐

40

N宁

¿

o 8

홍으

हㄷํㅇ

든 임

क

论

은

등

융

o

品

$\infty$.

는 응

亏

는 


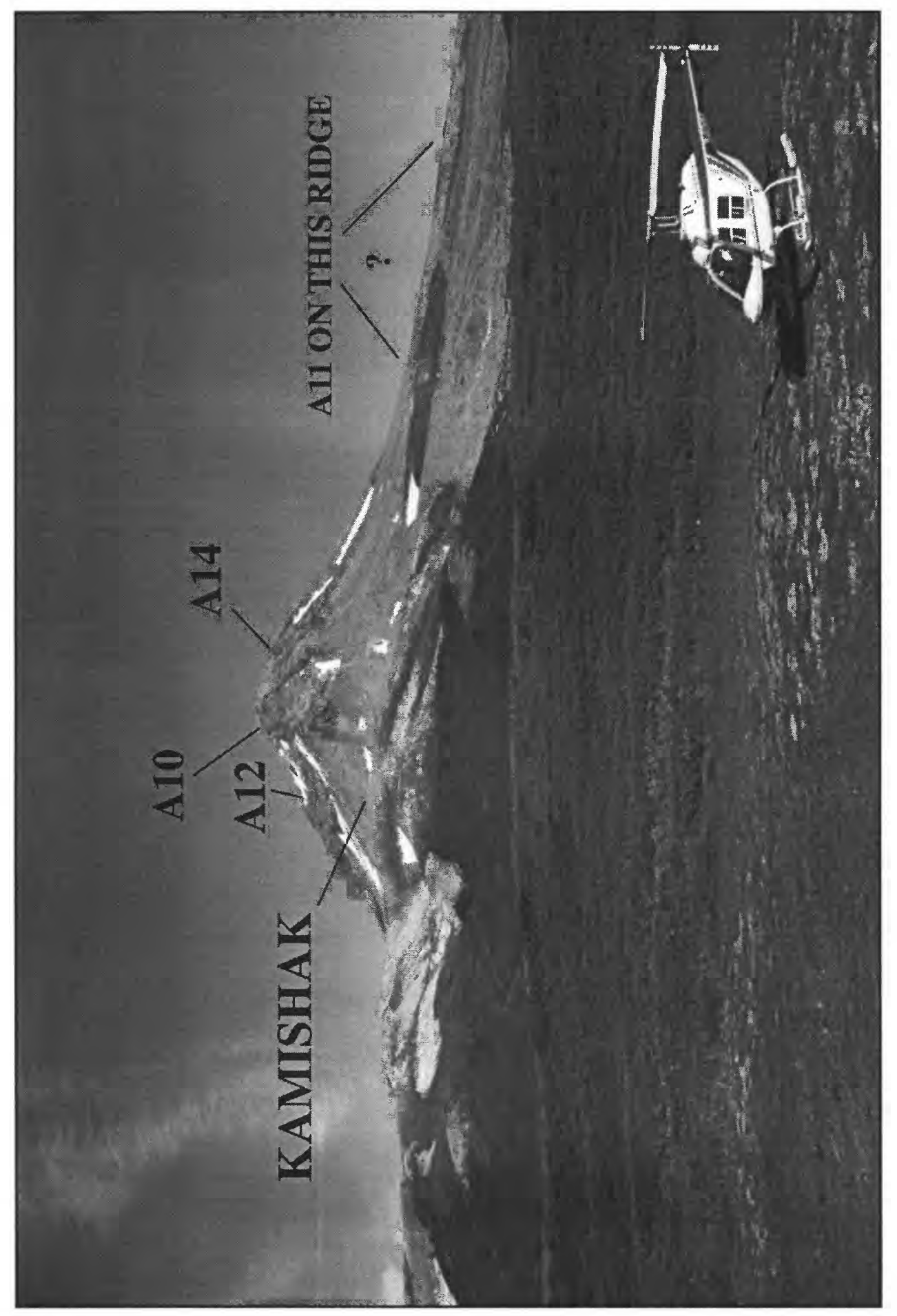

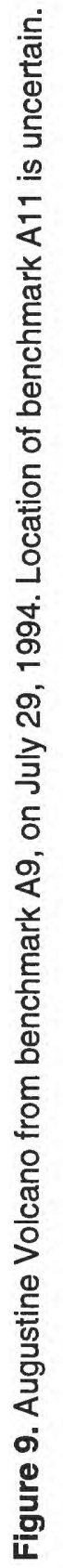

